KASVATUS\&AIKA

Katsaus

https://doi.org/10.33350/ka.74591

\title{
Sisällissota 1918 ja ammattikoulu
}

\author{
Jari Laukia
}

\section{Johdanto}

Suomen julistautuessa itsenäiseksi vuonna 1917 maan koulujärjestelmä oli jo hyvässä kehittymisvaiheessa. Kansakoulu oli aloittanut toimintansa vuonna 1863. Kesti tosin vielä pitkään ennen kuin kansakouluopetus kosketti kaikkia Suomen nuoria. Oppikouluasetus vuodelta 1872 puolestaan systematisoi ylempää sivistävää koulutusta. Eri ammattialojen koulutusta antavia oppilaitoksia, kauppaoppilaitoksia, maatalousoppilaitoksia ja teknillisiä oppilaitoksia oli toiminnassa useita. Helsingin yliopisto ja Teknillinen korkeakoulu vastasivat korkeammasta koulutuksesta ja tutkimuksesta. (Nykänen 2007, 20-22; Rousi 1986, 29 30; Klemelä 1999, 83-86.) Lisäksi toiminnassa oli erilaisia vapaan sivistystyön oppilaitoksia. Koulumaailman nuorin tulokas oli ammattikoulu. Ensimmäinen moderni ammattikoulu aloitti toimintansa Helsingissä vuonna 1899. Vuosisadan vaihteessa Suomessa uskottiin koulutukseen ja koulusivistykseen.

Vuoden 1918 sota oli järkytys sivistyneistölle ja koulutususkolle. Esimerkiksi Suomen opettajayhdistyksen kokouksessa syyskuussa todettiin, että kansalaiskasvatus oli epäonnistunut. Itsetutkiskelu kohdistui varsinkin punaisten puolella taistelleiden sivistystasoon. Kasvatustyötä olikin tehostettava. Opetuksella tuli jakaa tietoa yhteiskunnan toiminnasta, kehittää yhteiskunnallista vastuuntunnetta ja yhteisöllisyyttä. Koti, uskonto ja isänmaa olivat keskeisiä koulutuksellisia arvoja. (Tuomaala 2004, 302-303; Tepora 2011, 234; Jauhiainen 2011, 113-114.) Koulutuksen kehittäminen näkyi lainsäädännössä sodan jälkeen. Vuonna 1920 annettiin itsenäisyyden ajan ensimmäiset asetukset ammattikouluista, ja vuonna 1921 eduskunta vahvisti oppivelvollisuuslain.

Seppo Hentilä tarkastelee teoksessaan Pitkät varjot, muistamisen historia ja politiikka sisällissodan vaikutuksia eri yhteiskuntaelämän alueilla. Sota jakoi kansakuntaa poliittisesti, ja eri kulttuurielämän aloille syntyi jakolinja sisällissodan rintamalinjojen mukaisesti. Koulutus oli yksi alue, jossa voittajat ja häviäjät joutuivat kohtaamaan (Hentilä 2018, 8687). Oona Ilmolahti toteaa tutkimuksessaan Eheys ja ennakkoluulo, että häviäjien lasten koulutie voittajien kansakoulussa oli jännitteinen. Kouluhallituksessa tavoiteltiin kansakoulun neutraalisuutta suhteessa vuoden 2018 sotaan. Virallinen tavoite oli, että koulu toimisi yhteiskuntaa eheyttävästi. Käytännön koulutyössä oli kuitenkin jännitteitä valkoisten opettajien kohdatessa punaisten perheiden oppilaita. Esimerkiksi vuoden 1918 sotaa koskevien asioiden käsittelyssä syntyi opettajan ja oppilaiden kesken erimielisyyksiä varsinkin työläispaikkakunnilla. (Ilmolahti 2017, 163-173.)

Lynn Davies tarkastelee teoksessa Education and Conflict koulutusta monipuolisesti 
sodan ja konfliktien näkökulmasta. Tietojen ja taitojen ohella tunteiden merkitys koulutuksessa korostuu konfliktin yhteydessä (Lynn 2004, 10). Koulu voi toimia konflikteja ehkäisevästi, mutta Lynn pohdiskelee myös, miten koulutus voi rakentaa ja korostaa yhteiskuntaluokkien välisiä eroja ja sitä kautta vaikuttaa yhteiskunnallisten konfliktien syntymiseen. Joissain tilanteissa koulu voi olla mukana muokkaamassa oppilaiden mielialoja väkivallalle suotuisiksi (Lynn, 54, 114).

\section{Aikarajaus ja lähdeaineisto}

Tässä katsauksessa tarkastelen suomalaista ammattikoulua sisällissodan aikana ja sodan jälkeen vuosina 1918-1938. Suomen itsenäistyessä vuonna 1917 toimi ammattikoulu seitsemässä kaupungissa. Aikarajaukseen on vaikuttanut sisällissota ja ammattikoulun vaiheet 1920- ja 1930-luvuilla. Vuonna 1938 valmisteltiin jo uutta ammattikoulua koskevaa lakia, jolla oli vaikutuksensa koulutukseen heti 1940-luvun alussa. Sisällissota loi laajasti varjonsa suomalaiseen yhteiskuntaan 1920- ja 1930-luvuilla. Nämä varjot hälvenivät 1940-luvun loppupuolelta alkaen toisen maailmansodan ja yhteiskunnallisen muutoksen takia. Keskeinen tutkimuskysymys tässä artikkelissa on, mitä vaikutuksia vuoden 1918 sisällissodalla oli ammattikoulujen toimintaan, opetuksen toteuttamiseen ja opetuksen sisältöihin sodan aikana ja sodan jälkeen 1920- ja1930-lukujen Suomessa.

Näihin kysymyksiin etsin vastauksia komiteamietinnöistä, aikalaislähteistä ja tutkimuskirjallisuudesta. Sisällissodan vaikutuksia koulutukseen on sivuttu tutkimuksissa. Oona Ilmolahden tutkimuksessa Eheys ja ennakkoluulo paneudutaan erityisesti sisällissodan kansakoulussa aiheuttamiin jännitteisiin (Ilmolahti 2017). Ammattikoulua historian valossa on ryhdytty enemmälti tutkimaan 1990-luvulta lähtien (esim. Heikkinen 1995; Klemelä 1999). Omassa väitöskirjatutkimuksessani Ammattikoulu Suomessa 1899-1987 sivutaan ammattikoulun toimintaa myös 1920- ja1930-luvuilla. Joissakin ammattikoulua koskevissa historiikeissa viitataan sotaan ja sen seurauksiin. Tämä kirjoitus noudattelee sitä kirjoittamisen genreä, jossa koulutus kytkeytyy muuhun yhteiskunnan toimintaan. Esimerkiksi Jyrki Kaarttinen on osoittanut, että koulutus kytkeytyy politiikkaan, ja että koulutus ja politiikka ovat toisistaan riippuvaisia. Koulutus on aina tavalla tai toisella sidoksissa kulloiseenkin yhteiskunnan poliittiseen järjestelmään. (Kaarttinen 2017.)

\section{Ammattikoulu - koulutusta ja kasvatusta kaupunkien työläisnuorille}

1900-luvun alussa koulu ylläpiti Suomessa yhteiskuntaluokkien eroja. Luokka-asemaan kuului vastakkainasettelu: omaan luokkaan kuuluvat hahmotettiin samankaltaisina ja toiset erilaisina (Ilmolahti 2017, 28). Kansakoulussa tämä näkyi koulun jakautumisena sivistyneistön lapsille suunnattuun valmistavaan kouluun ja muille suunnattuun kansakouluun. Luokkajako näkyi myös koulun jakautumisena oppikouluun ja ammattikouluun. Ammatillisen koulutuksen sisällä myös eri alojen koulutus jakoi opiskelijoita yhteiskunnallisen taustan mukaan. Ammattikoulun tehtävä oli kouluttaa työläistaustaisista perheistä tulevista nuorista työväkeä. Esimerkiksi kaupallisen alan oppilaitoksissa opiskelijat tulivat enimmäkseen keskiluokkaisista virkamiesperheistä, maatalousoppilaitoksissa puolestaan opiskelijat olivat enimmäkseen talonpoikaistaustaisia. Toki eri oppilaitoksissa oli opiskelijoita eri yhteiskuntaluokista. Käytännöllisten työtaitojen oppiminen on vuosien saatossa tapahtunut hyvinkin eri tavoilla: työssä ja työpaikalla vanhempien ja kokeneempien työntekijöiden opastamana, oppisopimustyyppisessä koulutuksessa yrityksissä sekä erilaisissa oppilaitok- 
sissa ja kouluissa. Vuoden 1920 asetus mainitsi ammattikoulun rinnalla ammattioppilaskoulut, jotka oli tarkoitettu jo työelämässä oleville henkilöille. Opetus tapahtui pääsääntöisesti iltaisin ja oli osa-aikaista. (Laukia 2013, 92.) Tekniseen osaamiseen ja teollisuuden erilaisiin tehtäviin liittyvää koulutusta annettiin eri tasoilla - koulu, opisto, korkeakoulu sen mukaan, minkälaisiin tehtäviin koulutus oli suunniteltu: työntekijä, esimies, suunnittelija, yrityksen johto. Vuoden 1923 säädösten pohjalta alkanut oppisopimuskoulutus puolestaan oli pääsääntöisesti suunnattu jo työkokemusta omaavalle aikuisväestölle. Näihin päiviin saakka oppisopimuskoulutus on ollut leimallisesti aikuisväestön ammatillista koulutusta. Eri ammattialojen koulutus syntyi ja kehittyi eri aikaan ja hallinnollisesti toisistaan erillään. 1960-luvulle saakka koulutus toimi hallinnollisesti seitsemän ministeriön alaisuudessa (Laukia 2013, liite 1).

Ammatillisen koulutuksen monitahoisuudesta ja toteutusmuotojen ja opiskelijoiden erilaisuudesta johtuen on näin ollen tarpeen rajata tutkittavaa kohdetta. Tässä artikkelissa tutkimuskohteena on ammattikoulu. Ammattikoulu tarkoittaa tässä katsauksessa tekniikan, käsityön ja teollisuuden ammatteihin koulutusta antavaa koulua, joka oli tarkoitettu nuorille, kansakoulun päättäneille oppilaille. Koulut saivat toimintaansa yhteiskunnan tukea, mutta omistajatahot, joko kunnat tai yksityiset tahot joutuivat kattamaan kuluja myös itse. Oppilailta ei vaadittu aiempaa työkokemusta. Tässä katsauksessa käsiteltävänä ajanjaksona ammattikoulu kesti yleensä kaksi vuotta, ja pääsyvaatimuksena kouluun oli kuusivuotisen kansakoulun oppimäärä. Joillakin paikkakunnilla ammattikoulun rinnalla tai sijalla toimi kansakoulun jatkoluokkia, jotka myös tarjosivat työ- tai käsityön opetusta. Kansakoulun jatkoluokat toimivat eri hallinnon alaisuudessa kuin ammattikoulut ja niiden toimintamalli oli erilainen. Kansakoulut toimivat opetushallituksen ja opetusministeriön alaisuudessa, ammattikoulut puolestaan teollisuushallituksen ja myöhemmin kauppa- ja teollisuusministeriön alaisuudessa. ${ }^{1}$ Tästä syystä olen rajannut jatkoluokat tämän katsauksen ulkopuolelle.

Ammattikoulu oli perustettu kouluttamaan työläistaustaisia kaupunkilaislapsia. Voidaan siten olettaa, että myös vuoden 1918 sisällissodan jälkeen suurin osa ammattikoulujen opiskelijoista tuli työläistaustaisista perheistä. Aiheuttiko sisällissota erityisiä jännitteitä tai konflikteja 1920- ja 1930-lukujen ammattikoulussa, jos oletetaan, että opettajat ja opiskelijat tulivat sisällissodan näkökulmasta eri puolilta rintamalinjaa?

\section{Ammattikoulun kasvatustehtävä}

Vapaamielinen talouspolitiikka ja viimeistään vuoden 1879 elinkeinolaki merkitsivät ammattikuntalaitoksen koulutuksellisen roolin vähittäistä häviämistä. Oli tarpeen järjestää ammatillinen koulutus uudella tavalla. Ensimmäinen ammattikoulu, Helsingin poikain valmistava ammattikoulu, aloitti toimintansa vuonna 1899. (Laukia, 2013.) Suomen itsenäistymiseen vuoteen 1917 tultaessa toimi seitsemässä kaupungissa ammattikoulu. ${ }^{2}$ Helsingissä, Viipurissa, Porissa ja Kotkassa oli sekä tyttöjen koulu että poikien koulu (Laukia 2013, 8081). Vuonna 1910 ammattikouluissa opiskeli 422 opiskelijaa. Vuonna 1920 niissä opiskeli 833 opiskelijaa. (Laukia 2013, liite 9.) Valtakunnallisesti opiskelijamäärä oli pieni verrattuna kansakouluun tai oppikouluun. Esimerkiksi oppikoulujen opiskelijamäärä kasvoi 1920luvun aikana 30 000:sta 50 000:een (Laukia 2013, liite 8.) Ammattikoulu on kuitenkin tähän katsaukseen riittävän kompakti ja rajattavissa oleva tutkimuskohde, jonka tutkiminen omalta osaltaan tuo lisävalaistusta asetettuun tutkimuskysymykseen. Lisäksi pienestä

1 Hallinnollinen hajanaisuus Suomen koulujärjestelmässä vallitsi 1970-luvulle saakka.

2 Näitä kaupunkeja olivat Helsinki, Pori, Kotka, Porvoo, Viipuri, Tampere, Kuopio. 
ammattikoulun alusta kasvoi vähitellen nykyinen ammattioppilaitos, joka on merkittävin ammatillista koulutusta antava oppilaitos Suomessa.

Oppipoikajärjestelmän loppumisen jälkeen perustetuilla ammattikouluilla oli heti varhaisvaiheessa kasvatuksellisia tehtäviä. Vaikutteita ammattikoulun perustamiseen haettiin ulkomailta, erityisesti Keski-Euroopasta ja Skandinavian maista. Koulujen perustamisen taustalla oli kaksi keskeistä tekijää. Ensinnäkin nouseva teollisuus ja liike-elämä tarvitsivat ammattitaitoista työvoimaa. Ammattitaitoisen työvoiman koulutus tapahtui kuitenkin hyvin monella tavalla ja tässä ammattikoululla oli vähäinen merkitys tarvittavan työvoiman määrään nähden. Toisekseen kaupungistuminen ja kansalaisvapauksien lisääntyminen lisäsivät kasvatuksellista ja sivistyksellistä tarvetta myös kansakoulun jälkeen. Ammattikoulu oli leimallisesti tarkoitettu työläistaustaisille kansakoulun päättäneille nuorille, jotka ikänsä puolesta eivät vielä päässeet kunnon palkkatöihin. Kansakoulun päättyessä oppilaat olivat usein 13-vuotiaita. Alle 15-vuotiaiden lasten palkallinen työnteko oli luvanvaraista ja säädeltyä. Usein nuoret tekivät erilaisia väliaikaistöitä: toimivat juoksupoikina, kengänkiillottajina, kotiapulaisina. Joutilaisuuden ja epävarman tulevaisuuden kaupunkiympäristössä pelättiin aiheuttavan lasten ja nuorten huliganismia ja rikollisuutta (Laukia 2016, 305-306).

Talonpoikaisessa yhteiskunnassa työläistaustaiset nuoret hakivat identiteettiään (Karttunen 2007, 8). Helsinkiläistä 1900-luvun alun huliganismia tutkinut Kari Koskela liittää katujen levottomuuden voimakkaaseen maalta kaupunkiin suuntautuneeseen muuttoliikkeeseen, työläistaustaisten nuorten omaehtoisen kulttuurin syntymiseen sekä näköalattomuuteen työelämässä (Koskela 2018, 27-28, 127-128).

Sivistyneistössä esiintyi myös mielipiteitä, joiden mukaan kaupunkilaisympäristö ei ollut lapsille yhtä sovelias ja kasvattava kuin maaseutuympäristö. Työläisvanhempien osaamista ja kykyä kasvattaa lapsiaan kunnollisesti epäiltiin.

Teollisuushallituksen ammattikoulujen tarkastaja, filosofian maisteri, arkkitehti Jalmari Kekkonen hahmotteli ammattikoululle kasvatuksellisia tehtäviä. Ammattikoulun tavoitteena oli kasvattaa porvarillisen, liberalistisen yhteiskunnan keskiluokkaisia työlaiskansalaisia. Työläiskansalaisen tunnusmerkkejä olivat ahkeruus, työteliäisyys ja raittius. Myös säästäväisyys ja aktiivinen toiminta omien elinolojen kohentamiseksi oli tärkeää. Demokratisoituva ja liberalisoituva yhteiskunta mahdollisti kansalaisille aktiivisen ammatillisen ja yhteiskunnallisen toiminnan. (Kekkonen 1916, 21-23; Kettunen 2001, 64-65.) Työläiskansalainen pystyi ammattitaidollaan ja työllään ansaitsemaan elantonsa itselleen ja perheelleen. Tavoitteena oli lieventää yhteiskunnallisia ristiriitoja. Yhteiskunnallinen kasvatus näyttäytyi kasvatuksena isänmaallisuuteen. Oppilaiden toivottiin pysyvän erossa aikakauden vallankumouksellisista liikkeistä. (Kekkonen 1916, 55; Laukia 2013, 83.) Ammattikoulu yhtäältä ylläpiti yhteiskunnallista luokkajakoa suuntaamalla koulutusta erityisesti kaupunkien työläistaustaisille lapsille, mutta toisaalta pyrki koulutuksen avulla estämään konfliktihakuista yhteiskuntaluokkien vastakkainasettelua ja kasvattamaan kansalaisia liberaaliin yhteiskuntaan.

\section{Ammattikoulu sisällissodassa}

Vuoden 1918 sodalla oli ymmärrettävästi suoria vaikutuksia ammattikoulujen toimintaan. Ammattikouluja oli perustettu kaupunkeihin, jotka olivat sisällissodan tapahtumien keskiössä: Tampere, Helsinki, Viipuri ja Pori. Tampereella ammattikoulun tiloja otettiin sotilaiden ja punaisten hallinnon käyttöön. Helsingissä ammattikoulu suljettiin 28. tammikuuta ja toiminta alkoi jälleen 26. huhtikuuta 1918. Joitakin ammattikoulujen opettajia ja oppilaita 
osallistui sotajoukkojen toimintaan. Sota ja levottomuudet vaikuttivat myös opiskelijamäärien vähenemiseen. Esimerkiksi Helsingissä poikain ammattikoulussa oli 150 oppilasta lukuvuonna 1916-1917, kun taas lukuvuonna 1918-1919 oppilaita oli 56 (Laukia 2013, 108; Eloranta-Koskela 1999, 32-33). Sodan päätyttyä valkoisen armeijan ylipäällikön C. G. E. Mannerheimin asettama päämajan tutkintoasiain toimikunta selvitteli julkisissa tehtävissä olleiden henkilöiden toimintaa sodan aikana. Tampereen ammattikoulun johtokunta ilmoitti koulun metallityönjohtaja Frans Hjalmar Myllymäen osallistuneen punaisen puolen valtuustoon ja eri komiteoihin sekä toimineen pankkitarkastajana. Koulun valutyöntekijä Eli Syvänen oli toiminut punaisten puolella kirvesmiehenä ja vartiomiehenä ja puutyönjohtaja Efraim Jaakkola oli kuulunut punaisten valtuustoon ja komiteoihin. (Laukia 2013, 109.)

Tampereen kaupunginvaltuusto erotti kaikki kolme tehtävästään. Jatkotutkinnassa, osittain Jalmari Kekkosen vaikutuksesta, Jaakkola ja Syvänen otettiin takaisin töihin. Myllymäen erottaminen pysyi voimassa. Ammattikoulujen tarkastaja Kekkoselle ei ammattikoulujen osalta kantautunut muualta pidätyksiä tai työpaikasta irtisanomisia sisällissodan vuoksi (Heikkinen 1995, 196). Toiminnan jatkuminen sodan jälkeen tapahtui kuitenkin mitä ilmeisimmin melkoisen joustavasti. Tätä näkemystä tukee myös esimerkiksi Helsingin ammattikoulun opiskelijamäärien kehitys sodan jälkeen. Lukuvuonna 1920-21 Helsingin poikain ammattikoulun opiskelijamäärä oli 155 , ja ylitti näin sotaa edeltäneen opiskelijamäärän (Eloranta-Koskela 1999, 40). Huomiota herättävää on myös se, että Helsingin kaupunginvaltuusto käsitteli heti ensimmäisessä kokouksessaan sodan jälkeen 16. huhtikuuta ammattikoulun toimintaa ja päätti hankkia koululle parempia työsalitiloja (Laukia 2013, 108-109). Sisällissodan jälkeen ammattikoulujen toiminta jatkui nopeasti myös siellä, missä se oli keskeytynyt.

Ammattikouluissa toimivien opettajien koulutustaustat poikkesivat kansakoulun tai oppikoulun opettajien taustoista. Ammattikouluissa oli teknillisen korkeamman koulutuksen saaneita opettajia, kansakoulunopettajia sekä opetushenkilöstöä, jolla oli alempi teknillinen tai muu ammatillinen koulutus (Laukia 2013, 149). Heidän poliittisesta vakaumuksestaan ei ole tutkimusta. Jalmari Kekkosen saamien sodan jälkiselvittelyjä koskevien tietojen perusteella näyttää kuitenkin siltä, että valtaosa opettajista tuki valkoisten toimintaa tai pitäytyi neutraaleina. Ilmolahden mukaan kansakoulunopettajista vain pieni osa osoitti vasemmistolaista aatetta. Punaisuussyytösten kohteeksi joutui 92 kansakoulunopettajaa, mikä oli noin 1,5 prosenttia maan kansakoulunopettajistosta (Ilmolahti 2017, 255).

\section{Koulutus tukee yhteiskunnan toipumista sodasta}

Sisällissota järkytti sivistyneistön tulevaisuudenuskoa. Selitystä sotaan etsittiin kapinallisten puutteellisesta sivistystasosta. Tämä puute tuli korjata kansallismielisellä, valkoisen Suomen arvoihin tukeutuvalla koulukasvatuksella. Näitä keskeisiä arvoja olivat koti, uskonto ja isänmaa. (Tuomaala 2004, 302-303; Tepora 2011, 234.)

Koulutuksen kehittäminen näkyi säädöksissä. Vuoden 1921 oppivelvollisuuslain toimeenpano kesti paikoitellen pitkälle 1930-luvun lopulle. Vuonna 1920 annettiin myös uusi asetus ammattikoulutusta varten. Asetuksen mukaan ammatteihin valmistava koulu oli kaksivuotinen koulu, joka oli tarkoitettu kansakoulun käyneille tytöille ja pojille. Hallinnollisesti ammattikoulu toimi kauppa- ja teollisuushallituksen ja kauppa- ja teollisuusministeriön alaisuudessa (Laukia 2013, 92-93).

Uudet asetukset noudattelivat vuoden 1918 sodan jälkeen mietintönsä antaneen ammat- 
tikasvatuskomitean linjauksia. Ammatteihin valmistava koulu oli nimenomaan työväen nuorisolle suunnattu koulu (Ammattikasvatuskomitea 1918:2, 10-11).

Ammattikoulun opiskelijamäärien kehitystä seurattaessa näyttää siltä, että ammattikoulujen toiminta toipui melkoisen nopeasti sotaa edeltäneeseen tasoon. Opiskelijamäärät lisääntyivät hiljalleen. Vuonna 1920 ammattikouluissa opiskeli 833 opiskelijaa, vuonna 1930 opiskelijoita oli 1982. Vuonna 1940 ammattikouluissa oli 3571 opiskelijaa. (Laukia 2013, liite 9.) Huolimatta tavoitteista lisätä koulutusta, vain pieni osa työläistaustaisista nuorista ja punaorvoista pääsi ammattikoulutuksen piiriin. Kaarnisen laskelmien mukaan sisällissodan jälkeen Suomessa oli noin 14200 sotaorpoa. Heistä noin 88 \% oli punaorpoja. Esimerkiksi Tampereen 488 punaorvosta 28 kävi valmistavaa ammattikoulua ja viisi jo työssä käyville tarkoitettua yleistä ammattikoulua (Kaarninen 2008, 152-153). Valtio ryhtyi tukemaan sotaorpojen koulunkäyntiä taloudellisesti. Myöhemmin 1920-luvulla tämä tukipolitiikka laajeni koskemaan myös muita vähävaraisia nuoria (Kaarninen 2003, 220).

Ilmolahti liittää punaorpo-käsitteeseen myös sellaiset punaisten lapset, joiden vanhemmat eivät kuolleet sisällissodan aikana, koska nämä lapset kokivat työläistaustaisuudesta johtuvaa toiseutta kouluelämässä (Ilmolahti 2017, 31). Sotien välisenä aikana suurin osa ammattikoulujen oppilaista tuli työläisperheistä. Esimerkiksi Tampereen ammattikoulussa vuoteen 1937 mennessä opiskelleista oppilaista noin $75 \%$ tuli työläistaustaisesta perheestä (Tampereen kaupungin poikain ammattikoulu XXVII, 1938-1939, Tampere 1939, TKA).

Kansakoulusta päässeiden työskentelyn suunnittelukomitean mukaan sisällissota ja ensimmäinen maailmansota olivat vaikuttaneet nuoren moraalikäsityksiin vahingollisella tavalla. Työläistaustaisten nuorten kasvatuksessa ja koulutuksessa oli kiinnitettävä huomiota siveellisesti kasvattavaan työhön. Tämmöisiä töitä olivat pojille esimerkiksi puiden pilkkominen ja kantaminen ja työskentely kasvimailla, ja tytöille ruoanlaitto ja lastenhoito. Myös ammatillisen koulutuksen lisäämiseen tuli kiinnittää huomiota. (KM 1933:4, Kansakoulusta päässeiden työskentelyn suunnittelun komitea.) Uljaksen mukaan kaupunkilaislasten opettamista työntekoon pidettiin myös perheissä tärkeänä. Kasvatuksellisten seikkojen lisäksi lasten työnteolla oli vaikutusta myös perheiden toimeentuloon (Uljas 2012).

Ammattikoulun tavoitteena oli kasvattaa kunnollisia yhteiskunnan kansalaisia. Ammattikoulun arvotavoitteet noudattelivat hyvinkin ajan hengen mukaisia koulutuksellisia arvoja. Opetusmenetelmät korostivat ahkeraa työntekoa. "Tehoisa valmistus ammattityöhön tuopi mukanaan yhteiskunnallisten ja siveellisten hyveitten sekä sivistävien tietojen kehittämistä: kunnon ammattilainen on myös kunnon kansalainen ja ihminen" (KM 1922:10, 7). Vallitsevat käsitykset miesten ja naisten tehtävistä näkyivät selvästi ammattikoulun tavoitteissa. Pojista koulutettiin itsensä ja perheensä elättämään kykeneviä ammattimiehiä, ja tytöistä työläisperheen äitejä, emäntiä ja kotiapulaisia. Ammattikoulutusta koskevissa komiteamietinnöissä suhtauduttiin kielteisesti tyttöjen suuntautumiseen kodin ulkopuoliseen ammattityöhön kotiapulaisen tai lastenhoitajan tehtävää lukuun ottamatta (KM 1928:8 I-II; Kaarninen 2001, 128-132). Kuitenkin ammattikouluja oli heti alusta alkaen perustettu sekä pojille että tytöille. Vuonna 1930 ammattikouluissa opiskeli 1133 poikaa ja 823 tyttöä. Ammattikoulu oli poikavaltainen, mutta ei kuitenkaan niin poikavaltainen kuin joissakin tutkimuksissa on esitetty (esim. Jauhiainen 2011). Esimerkiksi kansanedustaja Eva Somersalo työskenteli aktiivisesti tytöille suunnatun ammatillisen koulutuksen kehittämiseksi. Naisilla piti olla mahdollisuus työllistymiseen kodin ulkopuolella ja itsensä elättämiseen omalla työllään (Laukia 2013, 139-140; Kaarninen 1995, 80-82).

Sisällissota ei välittömästi tuonut suuriakaan muutoksia ammattikoulujen opetussuunnitelmiin. Opetussuunnitelmiin kuului ammatillisten oppiaineiden lisäksi äidinkieltä, kirjoitusharjoittelua, kansalaistietoa ja siveysoppia sekä voimistelua ja terveysoppia (Laukia 
2013, 133). Opetussuunnitelmien sisällöt oli määritelty jo ennen sotaa. Kansalaistiedon ja siveysopin opintojen sisältöalueina olivat perhe, talouteen liittyvät asiat, Suomen elinkeinot, työväenasiat kuten työpaikat ja koulutus, teollisuus ja liikenneolot. Samoin kansalaistiedon opinnoissa käsiteltiin valtion ja kunnan hallintoon liittyviä asioita. Opinnoissa käsiteltiin myös arvo- ja asennetason asioita kuten säästäväisyyttä, kunnianhimoa, käytöstapoja ja yhteisvastuullisuutta. Isänmaallisuus oli yksi käsiteltävä asia (Laukia 2013, 136-137). Opetussuunnitelmissa ei esiintynyt suoraa poliittista kasvatusta. Komiteamietinnön mukaan oppilaita tuli kasvattaa kristillisyyteen, pidättyvyyteen ja isänmaanrakkauteen. Mikäli käsiteltiin yhteiskunnallisia asioita, joista esiintyi erilaisia mielipiteitä, se tuli tehdä täysin puolueettomasti. (KM 1922:10, 27.)

Virallisen näkökulman mukaan kunnallisissa ammattikouluissa pyrittiin yhteiskunnallisesti eheyttävään opetukseen. Opetuksen mahdolliset ideologiset ja poliittiset painotukset varmasti riippuivat paljolti opettajista. David Lynnin näkökulmiin viitaten ammattikoulu pyrki mieluummin vähentämään yhteiskunnallisia konflikteja kuin korostamaan yhteiskunnallisia eroja. Työläistaustaisista nuorista huolehtiminen ja kasvattaminen korostuivat. Ammatilliset tavoitteet olivat usein melkoisen vaatimattomatkin. Työn opetuksella oli kasvattava ja sivistävä tehtävä. Lähtökohta oli, että varsinainen ammattitaito hankittaisiin työelämässä ammattikoulun jälkeen. Ammattikoulussa kasvatettiin työläiskansalaisia, jossa keskeistä oli ahkeruus, yhteisvastuullisuus, hyvät käytöstavat ja rehellisyys (Laukia 2013, 157). Lääke kunnon kansalaiseksi oli työ.

1920- ja 1930-luvuilla koulutus piti virallisissa linjauksissa yllä yhteiskunnan luokkajakoa eikä tukenut yhteiskunnallista nousua. Useimmat työläistaustaiset nuoret kävivät vain kansakoulun. Jotkut heistä pääsivät ammattikouluun kouluttautumaan työväenluokan eliitiksi. Sivistyneistön lasten koulutie kulki valmistavan koulun kautta oppikouluun. Työläistaustaisten nuorten hakeutumista oppikouluun pidettiin jopa haitallisena. Ylioppilastulvan vastustamiskomitean mietinnössä esitettiin oppikoulutuksen varaamista etupäässä ruotsinkielisen sivistyneistön edustajille. (KM 1935:12.)

Ilmolahden mukaan vasemmistopiireissä tuettiin koulutusta ja kasvatusta kansalaiseksi. Työkouluideologiaa koulutuksessa kannatettiin. Eduskunnassa käydyssä koulutuspoliittisessa keskustelussa etupäässä vasemmistopuolueiden edustajat esittivät ammattikoulun uudistamista ja koulutuksen lisäämistä sekä sivistyskäsitteen laajentamista siten, että se käsittäisi sekä ammatillisen sivistyksen että henkisen sivistyksen. (Ilmolahti 2017, 383; Laukia 2013, 157.)

\section{Valkoinen työntekijä - yksityisteollisuuden ammattikoulujen}

\section{kasvatukselliset tavoitteet}

Niissä kaupungeissa, joissa jo oli ammattikoulu, opiskelijamäärät kasvoivat maltillisesti 1920- ja 1930-luvuilla. Ennen sisällissotaa virinnyt ammattikoulujen perustaminen kuitenkin tyrehtyi sisällissodan jälkeen. Suomi kääntyi sisäänpäin, ideaalikansalainen oli omaa tilaa hoitava talonpoikaiskansalainen. Vuoden 1921 oppivelvollisuuslaki painotti ammatillisia valmiuksia antavien kansakoulun jatkoluokkien toimintaa. Vuosina 1918-1919 tapahtunut kunnallishallinnon uudistus ja poliittisesti valitut kunnanvaltuustot joutuivat harkitsemaan, perustettiinko kuntaan ammattikoulu vai oppivelvollisuuslaissa määrätty kansakoulun jatkoluokka (Jutikkala 1979, 156-171). Kansakoulun jatkoluokkien opinnot sisälsivät myös käytännön työtaitoja, ja opinnot oli tarkoitettu erityisesti kaupunkien ja teollisuuspaikkakuntien nuorille (Jauhiainen 2003, 56; Laukia 2013, 113). Kuntien kiinnostus 
ammattikoulujen perustamiseen virisi jälleen 1930-luvunlopulla, kun uusi ammattikoulua määrittävä lainsäädäntö paransi ammattikoulujen valtionapujärjestelmää.

Yksityisteollisuus perusti kunnallisten ammattikoulujen rinnalle omia kouluja. Kymiyhtiö oli perustanut oman koulun vuonna 1914. Varsinkin 1920- ja 1930- lukujen taitteessa yksityisteollisuus innostui perustamaan enemmän kouluja. Ammattikouluja perustivat mm. Lohjan Kalkkitehdas oy, G. A. Serlachius oy, Yhtyneet Paperitehtaat, Wärtsila oy, Ahlström oy, Nokian Aktiebolag ja Strömberg AB (Laukia 2013, liite 7).

Useimmat yksityisteollisuuden ammattikoulujen opetussuunnitelmat noudattelivat teollisuushallituksen kunnallisiin kouluihin hyväksymiä opetussuunnitelmia. Myös yksityisteollisuuden koulut kuuluivat valtionavun piiriin. Tosin valtionavun osuus kokonaismenojen kattamisesta jäi usein hyvin pieneksi, ja yritykset kattoivat suurimman osan oppilaitoksen kuluista omista varoistaan. Vuonna 1938 yksityisteollisuuden koulujen omaan yhdistykseen kuuluvia ammattikouluja oli kymmenkunta, ja niissä opiskeli 742 oppilasta (Laukia 2013, liite 7).

1920- ja 1930-lukujen taitteessa yhteiskunnallinen poliittinen tilanne Suomessa oli altis konflikteille. Monilla työpaikoilla työnantajien ja työntekijöiden välit olivat jännitteiset, ja aikakautta leimasivat monet poliittisluonteiset työtaistelut. Yksityisteollisuuden ammattikoulujen avoimena tavoitteena olikin poliittisesti luotettavien työntekijöiden kouluttaminen teollisuuden avaintehtäviin. Nämä tavoitteet näkyivät opiskelijavalinnoissa ja koulujen toiminnassa. Opiskelijavalinnoissa saatettiin ottaa huomioon oppilaan vanhempien yhteiskunnalliset näkemykset. Myönteinen suhtautuminen suojeluskuntaan ja hakijan isänmallinen maailmankatsomus vaikuttivat myös oppilaaksi valintaan. Tavoite oli, että oppilaat pystyivät vastustamaan sosialistista maailmankatsomusta. (Huovinen 2001, 29-30; Yksityisteollisuuden ammattikoulut 1939, 7, 23-26, 29-32.) Luotettavien työntekijöiden turvin tuotantolaitoksia voitiin pitää toiminnassa työtaisteluiden aikana. Kommunistien ja lakonmurtajajärjestöjen toiminta kärjisti ilmapiiriä työpaikoilla. Vuoden 1918 sodan varjossa kommunistin leima lankesi usein myös sellaisiin henkilöihin, joille se ei välttämättä kuulunut (Nordberg 1980, 318; Häggman 2006, 49-50).

Valkeakosken ammattikoulun johtaja Vilho Suihko oli huolissaan myös oppilaiden poliittisesta kasvatuksesta koulun jälkeen. Kasvatus voisi mennä hukkaan, jos nuori valmistuttuaan joutuisi vasemmistolaisten ajatusten vaikutuspiiriin kotioloissa. Nuoren siteet tällaiseen kotiin tuli katkaista. (Kaasinen 1988, liite 4; Laukia 2013, 124).

Koulujen järjestämällä vapaa-ajantoiminnalla oli ideologiseen kasvatukseen liittyviä tavoitteita. Kaikissa yksityisteollisuuden ammattikouluissa oli suojeluskuntatoimintaa, johon oppilaiden oletettiin osallistuvan. Esimerkiksi Valkeakoskella ammattikoulun oppilaat muodostivat suojeluskunnan komppanian. Urheilu ja ammunta olivat yleisiä vapaaajan harrastuksia (Laukia 2013, 123). Kouluissa oppilaat saivat valmiuksia myös maanpuo lustukseen ja yhteiskunnalliseen toimintaan liittyvään sotilaalliseen toimintaan. Näin joissakin tapauksissa koulu jopa koulutti käyttämään väkivaltaa yhteiskunnallisten kysymysten ratkaisemiseen (esim. Lynn 2004, 109-110).

1930-luvun lopulle tultaessa poliittisen kasvatuksen merkitys väheni. Koulutus oli tehnyt tehtävänsä ja teollisuuden avainpaikoille oli saatu koulutettua osaavia työntekijöitä. Myös yhteiskunnallisen vastakkainasettelun loiveneminen 1930 -luvun lopulle tultaessa vaikutti asiaan. Koulujen toiminnassa ammatilliset tavoitteet nousivat poliittisen kasvatuksen ohi. 1920- ja 1930-luvuilla yksityisteollisuuden ammattikouluissa oli poliittinen kasvatus kunnallisiin ammattikouluihin verrattuna selkeämmin esillä. (Tuomisto 1986, 158-163.) 


\section{Yhteenveto}

Vuoden 1918 sodan jälkeen ammattikoulujen toiminta palautui verraten nopeasti sotaa edeltäneeseen tilanteeseen. Sodan aikana laskeneet opiskelijamäärät palautuivat nopeasti sotaa edeltäneelle tasolle ja nousivat hiljalleen 1920- ja 1930-lukujen aikana. Virallisissa linjauksissa ammattikoululle haettiin yhteiskuntaa eheyttävää roolia. Koulutusta pyrittiin suuntaamaan mm. punaorvoille sekä vähävaraisista perheistä tuleville lapsille. Ammattikoulun opiskelupaikkoja ei kuitenkaan riittänyt lähimainkaan kaikille halukkaille. Asiaan vaikutti oppivelvollisuuslaki sekä ammatillisen koulutuksen valtiontuen epävarmuus. Samoin yleissivistävä koulu oli yhteiskunnallisessa arvostuksessa ammattikoulua korkeammalla.

Virallisen linjan mukaan ammattikoulujen opetuksessa pyrittiin suhtautumaan vuoden 1918 tapahtumiin neutraalisti. Kuitenkin ammattikoulu ylläpiti luokkakantaista yhteiskuntaa kouluttamalla työläisnuorisoa, jonka toivottiin pysyttelevän erossa kumouksellisiksi koetuista vasemmistolaisista poliittisista aatteista. Sisällissodan jälkeen eduskunnan vasemmistoryhmien edustajat korostivat käytännöllisen osaamisen ja henkisen osaamisen tasavertaisuutta, ja he pyrkivät opillisen sivistyksen laajentamiseen ja kansanvaltaistamiseen.

Ammattikoulun toiminnassa korostuivat kasvatukselliset tavoitteet ammatillisten tavoitteiden rinnalla. Myös ammatillisella osaamisella ja työnteolla oli kasvatuksellisia tavoitteita. Ahkeruus, työn kunnioittaminen ja itsestä ja perheestä omalla työllä huolehtiminen olivat työläiskansalaisen hyveitä. Työläiskansalaisten kasvattamisessa painottui työkouluajattelu. Käytännöllinen osaaminen ja työnteko olivat myös kasvattavia toimintoja. Työ oli paras tapa kasvattaa työläiskansalaisia.

Yksityisteollisuuden ammattikoulujen toiminnassa vuoden 1918 sodan vaikutukset näkyivät selkeästi. Ammattikoulujen tehtävänä oli kouluttaa ja kasvattaa poliittisesti luotettavia työntekijöitä teollisuuden avaintehtäviin. Varsinaisen opetuksen yhteydessä tapahtuneen kasvatuksen lisäksi poliittista kasvatusta tapahtui koulujen kerhoissa ja oppilaille suunnatussa suojeluskuntatoiminnassa. 1930-luvun lopulla kunnat ryhtyivät jälleen perustamaan omia koulujaan, ja yksityisteollisuuden ammattikoulujen toiminnassa vahvistuivat ammatilliset tavoitteet.

Ammattikoulun pedagogiset menetelmät ja kasvatukselliset tavoitteet oli suunniteltu jo ennen sisällissotaa. Sota ei aiheuttanut opetussuunnitelmiin kovin suuria muutoksia. Toiveena oli, että yhteiskunnallisia asioita käsiteltäisiin neutraalisti yhteisöä eheyttävällä tavalla. Ammattikoulujen perustaminen vilkastui 1960-luvun alussa elinkeinorakenteen muuttuessa, yhteiskunnan kaupungistuessa ja toisen maailmansodan jälkeen syntyneiden suurten ikäluokkien tullessa kansakoulun jälkeiseen kouluikään. Keskiasteen koulunuudistus 1970luvulla puolestaan toi ammattikoululle uskottavuutta lukiokoulun rinnalla.

\section{Lähteet}

KM 1918:2, Ammattikasvatuskomitea.

KM 1922:10, Jatko-opetuskomitean mietintö.

KM 1928:8 I-II, Ammattikasvatuskomitealta I ja Ammattikasvatuskomitealta II \& III Valtioneuvostolle.

KM 1933:4, Kansakoulusta päässeiden työskentelyn suunnittelun komitea.

KM 1935:12, Ylioppilastulvan vastustamiskomitean mietintö. 
Tampereen kaupungin poikain ammattikoulu XXVII, vuosikertomus 19381939, Tampere 1939, Tampereen kaupungin arkisto.

Yksityisteollisuuden ammattikoulut. Helsinki 1939.

\section{Kirjallisuus}

Ahonen, Sirkka 2003. Yhteinen koulu - tasa-arvoa vai tasapäisyyttä? Koulutuksellinen tasa-arvo Suomessa Snellmanista tähän päivään. Tampere: Vastapaino.

Davies, Lynn 2004. Education and Conflict. Complexity and chaos. London and New York: RoutledgeFalmer. https://doi.org/10.4324/9780203711804

Eloranta, Pekka \& Koskela, Juha (toim.) 1999. Polkusorvilla se alkoi. Vallilan Ammattioppilaitoksen 100-vuotishistoriikki. Helsingin kaupunki.

Heikkinen, Anja 1995. Lähtökohtia ammattikasvatuksen kulttuuriseen tarkasteluun. Esimerkkinä Suomalaisen ammattikasvatuksen muotoutuminen käsityön ja teollisuuden ajalla 1840-1940. Acta Universitas Tamperensis ser A vol. 442. Tampere: Tampereen yliopisto.

Hentilä, Seppo 2018. Pitkät varjot. Muistamisen historia ja politiikka. Helsinki: Kustannusosakeyhtiö Siltala.

Huovinen, Kari 2001. Nokian Ammattikoulut 1925-2000. Tampere: Domus-Offset Oy.

Häggman, Kai 2006. Metsän tasavalta. Suomalainen metsäteollisuus politiikan ja markkinoiden ristiaallokossa 1920-1939. Suomen Kirjallisuuden Seuran toimituksia 1055:2. Helsinki: Suomalaisen Kirjallisuuden Seura.

Ilmolahti, Oona 2017. Eheys ja ennakkoluulo. Työväenyhteisön ja kansakoulunopettajiston jännitteinen suhde Helsingissä sisällissodasta 1930-luvulle. Työväen historian ja perinteen tutkimuksen seura 2017. Turenki: Hansaprint.

Jauhiainen, Annukka 2011. Työläis- ja maalaisnuorison pidentyvä koulutie. Teoksessa Anja Heikkinen \& Leino-Kaukiainen, Pirkko (toim.), Valistus ja koulunpenkki. Kasvatus ja koulutus Suomessa 1860-luvulta 1960-luvulle. Helsinki: Suomalaisen Kirjallisuuden Seura, 111-120.

Jutikkala, Eino 1979. Tampereen historia III, vuodesta 1905 vuoteen 1949. Tampere: Tampereen keskuspaino.

Kaasinen, Juhani 1988. Teollisuuden yksityiset ammattikoulut Hämeen läänissä 19291939. Suomen historian pro gradu tutkielma. Tampereen yliopisto.

Kaarttinen, Jyrki 2017. Kansallissosialistinen kasvatus - Politiikkaa vai pedagogiikkaa? Kasvatus ja Aika 11(2), 73-79.

Kaarninen, Mervi 2008. Punaorvot 1918. Hämeenlinna: Minerva kustannus oy. Kariston kirjapaino.

Kaarninen, Mervi 2003. Nuoren tasavallan nuoriso-ongelmat. Oliko Suomessa nuoriso-ongelma? Teoksessa Aapola, Sinikka \& Kaarninen, Mervi (toim.), Nuoruuden vuosisata. Suomalaisen nuorison historia. Suomalaisen Kirjallisuuden Seuran toimituksia 909. Helsinki: Suomalaisen Kirjallisuuden Seura, 217-237.

Kaarninen, Mervi 2001. Ammattia vai perhettä varten. Tyttöjen ammattikoulutus 19201930-luvulla. Teoksessa Anttila, Anu-Hanna \& Suoranta, Anu (toim.), Ammattia oppimassa. Väki voimakas, 14. Tampere: Työväen historian ja perinteen tutkimuksen seura , $120-143$.

Kaarninen,Mervi 1995. Nykyajan tytöt. Koulutus, luokka ja sukupuoli 1920- ja 1930-luvun Suomessa. Helsinki: Suomen Historilallinen Seura. 
Kekkonen, Jalmari 1916. Kansalaistietoa ammattilaisille. Ammatillisia kouluja ja itseopiskelua varten. Helsinki: Otava.

Klemelä, Kirsi 1999. Ammattikunnista ammatillisiin oppilaitoksiin. Ammatillisen koulutuksen muotoutuminen Suomessa 1800-luvun alusta 1990-luvulle. Koulutussosiologian tutkimuskeskuksen raportti 48. Turku: Turun yliopisto.

Koskela, Kari 2013. Huligaanit. Katuelämää Sörkassa suurlakosta sisällissotaan. Helsinki: Suomalaisen Kirjallisuuden Seura.

Laukia, Jari 2013. Tavoitteena sivistynyt kansalainen ja työntekijä. Ammattikoulu Suomessa 1899-1987. Helsinki: Unigrafia Oy.

Laukia, Jari 2016. Kansalaiskasvatus ja sivistys ammattikoulussa 1900-1920. Teoksessa Saaritsa, Sakari \& Selin, Sinikka (toim.), Työväki ja sivistys. Väki Voimakas 29. Vantaa: Työväen historian ja perinteen tutkimuksen seura, 299-325.

Nordberg, Toivo 1980. Vuosisata paperiteollisuutta II. Yhtyneet Paperitehtaat Osakeyhtiö 1920-1951. Valkeakoski.

Tepora, Tuomas 2011. Sinun puolestas elää ja kuolla. Suomen liput, nationalismi ja veriuhri 1917-1945. Helsinki: WSOY.

Tuomaala, Saara 2004. Työtätekevistä käsistä puhtaiksi ja kirjoittaviksi. Suomalaisen oppivelvollisuuskoulun ja maalaisten kohtaaminen 1921-1939. Helsinki: Suomalaisen Kirjallisuuden Seura.

Tuomisto,J. 1986. Teollisuuden koulutustehtävien kehittyminen. Tutkimus teollisuustyönantajien ja kvalifikaatiointressien historiallisesta kehityksestä Suomessa. Tampereen yliopisto A:209,1986.

Uljas, Päivi 2012. Hyvinvointivaltion läpimurto. Pienviljelyhegemonian rapautumisen, kansalaisliikehdinnän ja poliittisen murroksen keskinäiset suhteet suomalaisessa yhteiskunnassa 1950-luvun loppuvuosina. Väitöskirjatutkimus, Helsingin yliopisto. Helsinki: Into Kustannus oy.

FT Jari Laukia työskentelee Haaga-Helia ammattikorkeakoulun Ammatillisen opettajakorkeakoulun johtajana. 